\title{
Correlation between Inflammatory Markers and Lipid Parameters in a Tunisian Coronary Artery Disease Group
}

\author{
Rihab Sendesni ${ }^{1}$, Dhaker Lahidheb ${ }^{2}$, Manel Ayoub ${ }^{1}$, Nedra Grira ${ }^{1}$, Dhekra Lafi' ${ }^{1}$, \\ Nejla Stambouli ${ }^{1}$, Mabrouka El Oudi ${ }^{1}$, Ezzedine Ghazouani ${ }^{3}$, Habib Haouala ${ }^{2}$, \\ Zied Aouni' ${ }^{1}$, Chakib Mazigh ${ }^{1}$ \\ ${ }^{1}$ Biochemistry Department, Research Unit UR12DN02, Military Hospital of Tunis, Tunis, Tunisia \\ ${ }^{2}$ Cardiology Department, Research Unit UR12DN02, Military Hospital of Tunis, Tunis, Tunisia \\ ${ }^{3}$ Immunology Department, Military Hospital of Tunis, Tunis, Tunisia \\ Email: aouni_zied@yahoo.fr
}

Received 30 April 2016; accepted 15 May 2016; published 18 May 2016

Copyright (C) 2016 by authors and OALib.

This work is licensed under the Creative Commons Attribution International License (CC BY).

http://creativecommons.org/licenses/by/4.0/

(c) (i) Open Access

\begin{abstract}
Aims: To evaluate the relationship between inflammatory biomarkers and lipid parameters in a Tunisian coronary artery disease group. Material and Methods: In the study, we have included 122 subjects with acute coronary syndrome (ACS) confirmed by coronary angiography, selected among patients admitted to the cardiology department and 162 subjects free of any cardiovascular disease, recruited from medical and paramedical volunteers. Lipid parameters, high sensitivity CRP (hsCRP) and proinflammatory cytokines (IL6, IL8 and TNF $\alpha$ ) were determined for all patients and controls. Results: A highly significant difference $\left(P<10^{-3}\right)$ was noted between the mean of the hsCRP in coronary patients $(14.65 \pm 9.81 \mathrm{mg} / \mathrm{L})$ compared to controls $(1.63 \pm 1.75 \mathrm{mg} / \mathrm{L})$. We note also a significant difference between the means of IL6 in the diseased population (11.56 \pm 8.23 $\mathrm{pg} / \mathrm{mL})$ compared to controls $(2.5 \pm 0.84 \mathrm{pg} / \mathrm{mL})$ with a value of $P<10^{-3}$. The hsCRP values are inversely correlated with the HDLc values. No association was found between IL 8 and the various lipid parameters. Patients having high IL6 values had higher levels of CT and CT/HDLc ratio. This correlation is statistically significant. Regarding TNF $\alpha$, there is a positive and significant correlation with CT and LDLc. Conclusion: Significant correlation was found between inflammatory markers and lipids profile. This may explain the role of inflammation in the development of cardiovascular disease.
\end{abstract}

\section{Keywords}

Inflammation, Lipids, Acute Coronary Syndrome

Subject Areas: Biochemistry

How to cite this paper: Sendesni, R., Lahidheb, D., Ayoub, M., Grira, N., Lafi, D., Stambouli, N., El Oudi, M., Ghazouani, E., Haouala, H., Aouni, Z. and Mazigh, C. (2016) Correlation between Inflammatory Markers and Lipid Parameters in a Tunisian Coronary Artery Disease Group. Open Access Library Journal, 3: e2635. http://dx.doi.org/10.4236/oalib.1102635 


\section{Background}

Cardiovascular disease (CVD), mainly acute coronary syndromes, nowadays is a real public health problem worldwide.

Atherosclerosis is the major cause of most diseases of the circulatory system, particularly acute coronary syndromes (ACS). It is a multi-factorial disease whose genesis involves genetic and environmental determinants leading to aggression of the arterial wall [1].

The risk for ACS is even faster than it has over associated aggravating factors there. These risk factors are numerous and are classified as non-modifiable risk factors (age, Saxony, heredity) and modifiable risk factors (diabetes, dyslipidemia, smoking, hypertension, obesity, alcohol ...) [2].

Apart from these traditional factors, other factors for assessing the cardiovascular disease risk have been suggested over the past thirty years as hyperhomocysteinemia, lipoprotein (a), chronic inflammation ... Indeed, the even moderate elevations of inflammatory markers such as C-reactive protein (CRP), interleukin 6 (IL6) and tumor necrosis factor (TNF) are increasingly considered as risk markers of CVD.

Most epidemiological studies have highlighted the existence of a relationship between these markers and the increased incidence of coronary disease [3].

However, other authors found no association between new inflammatory markers and severity of coronary disease [4].

We propose in this study to evaluate the relationship between inflammatory biomarkers and lipid parameters in a Tunisian coronary artery disease group.

\section{Material and Methods}

\subsection{Material}

This work was performed at the Tunis military hospital. In this prospective study we have recruited 284 individuals divided into two groups:

Patient population: in the study we have includes 122 subjects with ACS confirmed by coronary angiography, selected among patients admitted to the cardiology department.

Control population: 162 subjects free of any cardiovascular disease were recruited from medical and paramedical volunteers.

The study objectives and procedure were explained to all participants, before obtaining their consent to enroll into the study.

\subsection{Methods}

Data collection included the epidemiological, clinical and biological parameters.

Blood samples were taken in the fasting state for at least 12 hours.

Total cholesterol (TC), triglycerides (TG) and HDL cholesterol (HDL) were assayed using an enzymatic colorimetric method on the DxC800 Synchron ${ }^{\circledR}$ analyzer (Beckman Coulter, USA).

LDL-cholesterol (LDL cholesterol) was calculated by the Friedwald formula for TG values $\leq 4.5 \mathrm{mmol} / \mathrm{l}$. $[\operatorname{LDLc}(\mathrm{mmol} / \mathrm{L})=\mathrm{CT}(\mathrm{HDL}+\mathrm{TG} / 2.18]$.

The ApoAI, ApoB and Lp (a) were measured using a nephelometric method on immunonéphlémétrique BNII ${ }^{\circledR}$ analyzer (Siemens, Germany).

High sensitivity CRP (hsCRP) was measured by nephelometricanalyzer BNII ${ }^{\circledR}$ (Siemens, Germany).

Interleukins (IL6, IL8) and tumor-necrosis factor alpha (TNFa) were assayed by immunometric method with chemiluminescence detection on the Immulite ${ }^{\circledR} 1000$ (Siemens, Germany).

\subsection{Statistical Analysis}

Statistical analysis of various data collected was performed using SPSS Version 20.0 software (SPSS Inc, USA) for Windows (Microsoft Corporation, USA). The results are presented in absolute and percentage for qualitative variables and means \pm standard deviations $(\mathrm{m} \pm \mathrm{SD})$ for quantitative variables.

Comparisons between quantitative variables were performed using Student's $t$ test. The significance level was set at $\mathrm{P}=0.05$. 
The Spearman test was used to study the correlation between different parameters.

\section{Results}

\subsection{Descriptive Study}

Anthropometric and clinical characteristics of the study population are shown in Table 1.

\subsection{Lipid Parameters}

We studied the different lipid parameters in both groups. The results are shown in Table 2.

\section{3. hsCRP and Proinflammatory Cytokines}

Comparing the hsCRP and proinflammatory cytokines between the two groups is shown in Table 3.

Table 1. Distribution of anthropometric and clinical parameters in both groups.

\begin{tabular}{cccc}
\hline Parameters & Controls $(\mathrm{n}=162)$ & ACS $(\mathrm{n}=122)$ & $\mathrm{P}$ \\
\hline Age $(\mathrm{m} \pm \mathrm{SD}$; years) & $44.75 \pm 6.67$ & $63.86 \pm 10.06$ & $<10^{-3}$ \\
Sex ratio (M/W) & 1.45 & 1.71 & $\mathrm{NS}$ \\
Tobacco $(\%)$ & 30.4 & 58.2 & $<10^{-3}$ \\
Alcohol $(\%)$ & 1.2 & 2.5 & $\mathrm{NS}$ \\
BMI (m \pm SD $\left.; \mathrm{kg} / \mathrm{m}^{2}\right)$ & $26.28 \pm 3.54$ & $26.61 \pm 3.84$ & $\mathrm{NS}$ \\
Dyslipidemia $(\%)$ & 5.4 & 55.7 & $<10^{-3}$ \\
Diabetes $(\%)$ & 9.2 & 50 & $<10^{-3}$ \\
Hypertension $(\%)$ & 7.4 & 63.1 & $<10^{-3}$ \\
\hline
\end{tabular}

M: man; W: women; ACS: Acute Coronary syndrome; NS: not significant (>0.05); n: number.

Table 2. Comparison of the lipid profile between the two groups.

\begin{tabular}{cccc}
\hline Parameters & Controls $(\mathrm{n}=162)$ & ACS $(\mathrm{n}=122)$ & P \\
\hline CT $(\mathrm{mmol} / \mathrm{L})$ & $4.69 \pm 1.16$ & $4.58 \pm 1.30$ & 0.44 \\
HDLc $(\mathrm{mmol} / \mathrm{L})$ & $1.13 \pm 0.34$ & $0.94 \pm 0.32$ & 0.017 \\
CT/HDLc ratio & $4.43 \pm 1.42$ & $4.92 \pm 1.71$ & 0.931 \\
LDLc (mmol/L) & $2.97 \pm 1.03$ & $2.96 \pm 1.18$ & 0.04 \\
TG (mmol/L) & $1.24 \pm 0.85$ & $1.45 \pm 0.80$ & 0.23 \\
Apo AI (g/L) & $1.28 \pm 0.33$ & $1.23 \pm 0.25$ & 0.063 \\
Apo B (g/L) & $0.91 \pm 0.36$ & $0.99 \pm 0.31$ & 0.008 \\
Apo (B/AI) ratio & $0.72 \pm 0.31$ & $0.82 \pm 0.26$ & $<10^{-3}$ \\
\hline Lp(a) (g/L) & $0.13 \pm 0.14$ & $0.36 \pm 0.25$ & \\
\hline
\end{tabular}

Table 3. Of hsCRP and proinflammatory cytokines mean values in the study population.

\begin{tabular}{cccc}
\hline Parameters & Controls $(\mathrm{n}=162)$ & ACS $(\mathrm{n}=122)$ & $\mathrm{P}$ \\
\hline hsCRP $(\mathrm{mg} / \mathrm{L})$ & $1.63 \pm 1.75$ & $14.65 \pm 9.81$ & $<10^{-3}$ \\
IL8 $(\mathrm{pg} / \mathrm{mL})$ & $5.85 \pm 1.41$ & $5.34 \pm 0.76$ & $\mathrm{NS}$ \\
IL6 $(\mathrm{pg} / \mathrm{mL})$ & $2.5 \pm 0.84$ & $11.56 \pm 8.23$ & $<10^{-3}$ \\
TNF $(\mathrm{pg} / \mathrm{mL})$ & $6.2 \pm 1.61$ & $11.18 \pm 6.83$ & $<10^{-3}$ \\
\hline
\end{tabular}


A highly significant difference $\left(\mathrm{P}<10^{-3}\right)$ was noted between the mean of the hsCRP in coronary patients $(14.65 \pm 9.81 \mathrm{mg} / \mathrm{L})$ compared to controls $(1.63 \pm 1.75 \mathrm{mg} / \mathrm{L})$.

The difference of the IL8 averages between the ACS $(5.34 \pm 0.76 \mathrm{pg} / \mathrm{mL})$ and the control groups $(5.85 \pm 1.41$ $\mathrm{pg} / \mathrm{mL}$ ) is not significant.

We note a significant difference between theIL6 means in the diseased population $(11.56 \pm 8.23 \mathrm{pg} / \mathrm{mL})$ compared to controls $(2.5 \pm 0.84 \mathrm{pg} / \mathrm{mL})$ with a value of $\mathrm{P}<10^{-3}$.

Comparing TNF $\alpha$ values shows that there is a significant difference $\left(\mathrm{P}<10^{-3}\right)$ between coronary patients $(11.18 \pm 6.83 \mathrm{pg} / \mathrm{mL})$ and witnesses, $(6.2 \pm 1.61 \mathrm{pg} / \mathrm{mL})$.

\subsection{Correlations between Studied Parameters and Inflammatory Markers in the Coronary Group}

The hsCRP values are inversely correlated with the HDLc values (Figure 1). No association was found between IL 8 and the various lipid parameters. Patients having high IL6 values had higher levels of CT (Figure 3) and $\mathrm{CT} / \mathrm{HDL}$ ratio (Figure 4), this correlation is statistically significant.

Regarding TNF $\alpha$, there is a positive and significant correlation with CT (Figure 5) and LDLc (Figure 6). The results of Spearman correlation test are shown below.

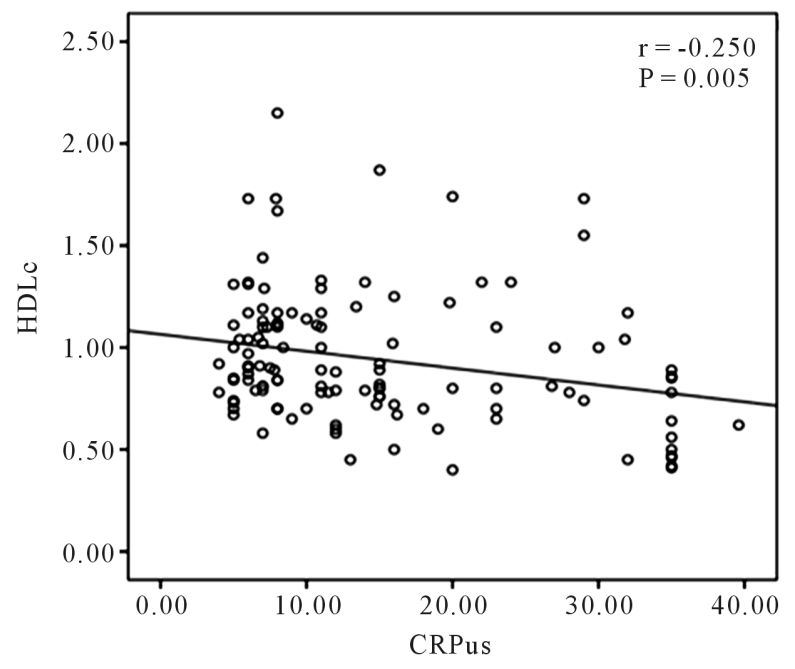

Figure 1. Correlation between la hsCRP and HDLc.

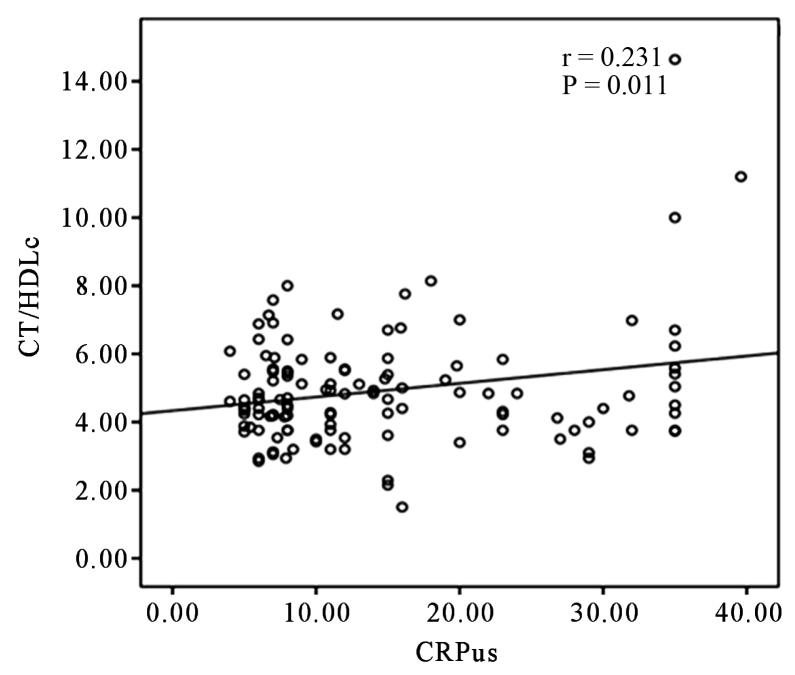

Figure 2. Correlation between hsCRP and CT/HDLc ratio. 


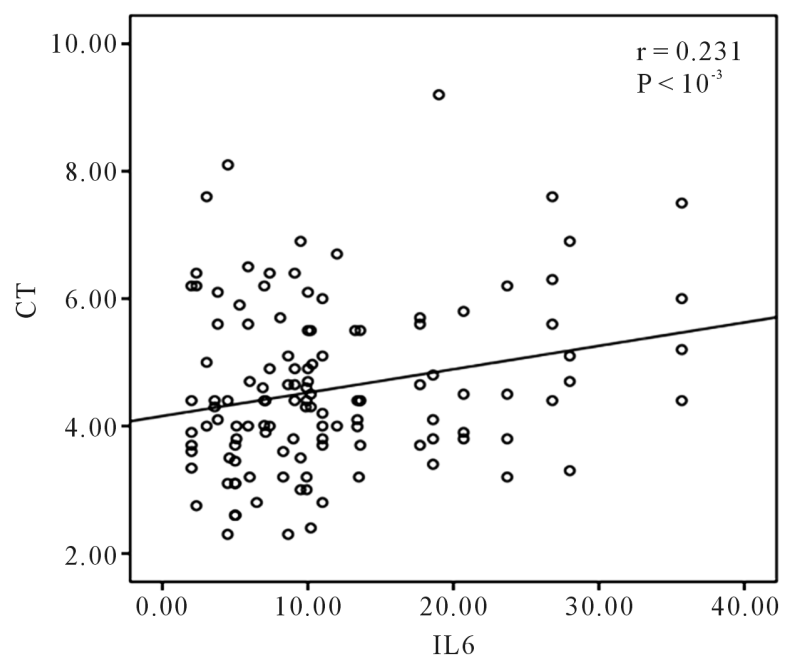

Figure 3. Correlation between IL6 and totalcholesterol.

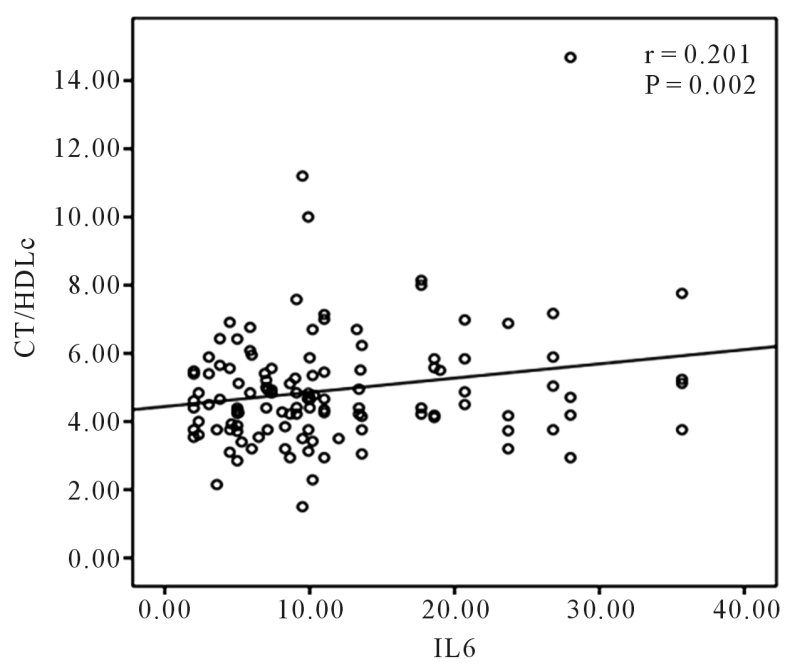

Figure 4. Correlation betweenIL6 and CT/HDLc ratio.

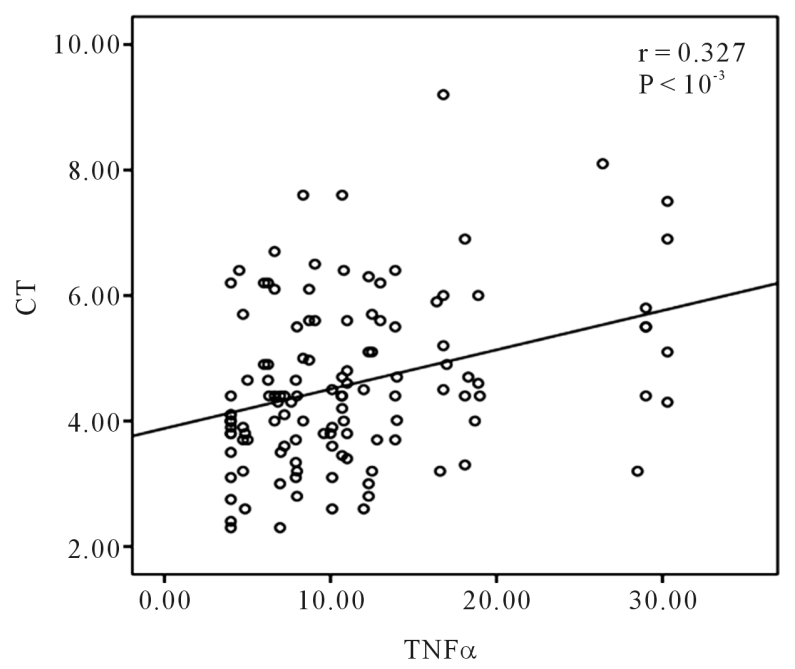

Figure 5. Correlation between TNF and total cholesterol. 


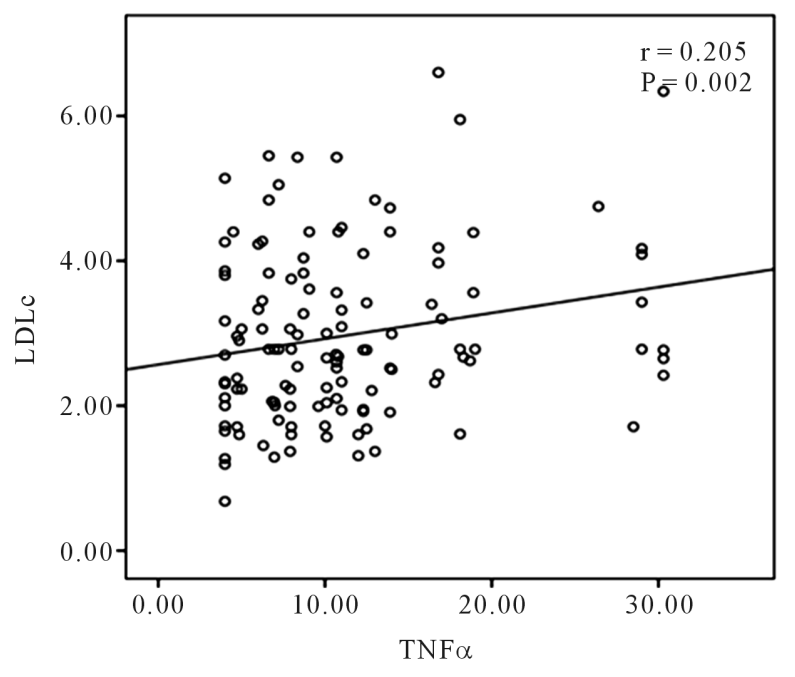

Figure 6. Correlation between TNF $\alpha$ and LDLc.

\section{Discussion}

ACS are multi-factorial diseases. They are the result of the synergistic combination of several risk factors. The role of inflammation has been widely debated.

The analysis of our study shows an IL6 average significantly higher in coronary patients compared with controls.

Several studies [5]-[7] have shown that IL6 and other pro-inflammatory cytokines were significantly increased in patients with acute coronary syndrome.

Other studies [8] [9] reported that the IL6 is a poor prognostic factor and can identify high cardiovascular risk patients.

The IL-6 is a cytokine secreted by many cell types and in particular by the macrophages and smooth muscle cells of the atherosclerotic lesion [10]. Indeed, IL-6 stimulates the expression of endothelial adhesion proteins associated with chemokines to promote inflammatory cells adhesion and platelet aggregation resulting in the theatheromatous plaque formation. On the other hand, IL-6 can activate complement, which affects thenitric oxide production and endothelin-1, resulting in endothelial dysfunction. IL-6 promotes the expression of Plasminogen Activator Inhibitor 1 (PAI-1) contributing to coagulation disorders and thrombus formation [11].

In our series, the average of TNF $\alpha$ was significantly higher in coronary patients compared with controls.

It has been shown that theTNF plasma level correlates with the load of atherosclerosis assessed by carotid ultrasound [12]. A Saraux et al. [13] reported that treatment with anti-TNF reduces inflammation and subsequently decreases cardiovascular risk.

TNFa is a pro-inflammatory cytokine secreted by monocytes macrophages, lymphocytes and mast cells and macrophages involved in the atherosclerotic plaque. He is involved in the production of chemokines, IL6 and CRP and leukocyte recruitment during the inflammatory response [14].

The analysis of our results showed a significant difference hsCRP rate in coronary patients compared with controls.

Several studies have shown that hsCRP is not only a marker of inflammation but also is a direct cause of cardiovascular disease [15]-[17].

CRP is characterized by its pro-atherogenic effects. Indeed, CRP acts on vascular endothelial cells by activating adhesion and promoting the LDLc aggregation. These actions, coupled with pro-inflammatory properties, cause a deleterious effect on the vascular wall and are directly involved in atherogenesis [18].

It has been experimentally demonstrated that CRP specifically binds to the oxidized LDLc and particularly LDLc present within atherosclerotic plaques [19]. Furthermore, the addition of CRP to LDLc in cell culture systems showed a stimulation of the foam cells production, which is a typical feature of atherosclerotic plaques [20]. CRP decreased actively the eNOS expression and activity (endothelial nitric oxide synthase) in epithelial cells [21] and encouraged endothelial cells to produce greater concentrations of Plasminogen Activator Inhibi- 
tor-1 [22].

The analysis of our results showed a negative linear correlation between CRPus and HDLc $(\mathrm{r}=-0.250$ and $\mathrm{P}$ $<0.05)$.

Our results are consistent with other studies that have reported a negative correlation between the plasma concentration of HDLc and that of hsCRP in patients with low HDLc levels, but not in those with normal or elevated HDLc levels [23] [24].

Mascarenhas F-Melo and al [25] have also shown that low HDLc is strongly associated with a high concentration of hsCRP.

These results are similar to those obtained by Wadham $\mathrm{C}$ et al. [26] who reported that HDL inhibitshs CRP and reduces the expression of inflammatory cell adhesion proteins.

Similarly, other studies [27] have also indicated that HDL inhibits cytokines induce expression of inflammatory adhesion molecules in endothelial cells. These results demonstrate potent anti-inflammatory capacity of HDL, which could explain the protective effect of HDL against atherogenesis.

The hsCRP is associated with a disorder of lipid profile such as an increase in total cholesterol, triglycerides and LDL cholesterol and lower HDL. But the mechanism is not entirely clear. Further studies are needed to assess the relationship between hsCRP and lipid profile [28].

In our study, we found a positive linear correlation betweenTNF $\alpha$ plasma levels with total cholesterol $(\mathrm{r}=$ 0.327 and $\left.\mathrm{P}<10^{-3}\right)$ and LDLc $(\mathrm{r}=0.205$ and $\mathrm{P}<0.05)$.

Demimbras B et al. [29] have found that the $\mathrm{TNF} \alpha$ correlates positively with triglycerides and negatively with HDLc in patients with myocardial infarction.

Jovinge S et al. [30] found that TNFa is positively associated with total cholesterol, LDL cholesterol and TG while it is negatively associated with HDLc in hyperlipidemic patients.

TNFa interferes with lipid homeostasis and activates the pro-atherogenic pathological processes [31].

TNFa may directly alter lipid metabolism by inhibiting the free fatty acids absorption and lipogenesis and stimulation of their release via lipolysis. This contributes to dyslipidemia [32].

Our results shows a positive linear correlation between IL6, total cholesterol $\left(\mathrm{P}<10^{-3}\right)$ and TC/HDLc ratio (P $<0.05)$.

Vijaya BM et al. [33] found a positive correlation between IL-6 and total cholesterol, triglycerides, LDL cholesterol and a negative correlation with HDLc in patients with hypertension. These researchers considered as dyslipidemia contributes to increased IL6 rates.

Several authors have suggested that IL6 with other pro-inflammatory cytokines can influence HDLc levels of by modifying the triglycerides lipase activity [34].

In addition, it has been shown that proinflammatory cytokines inhibit LPL activity and enhance the lipolytic activity of endothelial lipase. These two actions are associated with low levels of HDLc during the acute or chronic inflammatory state [35] [36].

\section{Conclusions}

In this study, a significant correlation was found between inflammatory markers and lipid profiles. This may explain the role of inflammation in the development of cardiovascular disease.

Inflammatory markers values can be related to an increase of the extent of coronary artery disease and therefore the degree of severity of the disease.

These markers may also have a potential role in predicting the severity of coronary artery disease. We propose their use in clinical practice not only as predictive biomarkers of cardiovascular events but also for the screening and management of high-risk patients.

\section{References}

[1] Paul, J.L. and Baudin, B. (2009) Physiopathologie de l'athérosclérose et marqueurs précoces. Revue Française des Laboratoires, 409, 41-50. http://dx.doi.org/10.1016/s1773-035x(09)70199-6

[2] Baudin, B., Cohena, A., Garcias, F.B., Meuleman, C., Dufaitre, G., Ederhy, S., et al. (2009) Données épidémiologiques des maladies cardiovasculaires et prise en charge des accidents cardiovasculaires. Revue Française des Laboratoires, 409, 27-39. http://dx.doi.org/10.1016/s1773-035x(09)70198-4

[3] Madjid, M. and Willerson, J.T. (2011) Inflammatory Markers in Coronary Heart Disease. British Medical Bulletin, 
100, 23-38. http://dx.doi.org/10.1093/bmb/ldr043

[4] Sukhija, R., Fahdi, I., Garza, L., Fink, L., Scott, M., Aude, W., et al. (2007) Inflammatory Markers, Angiographic Severity of Coronary Artery Disease, and Patient Outcome. American Journal of Cardiology, 99, 879-884. http://dx.doi.org/10.1016/j.amjcard.2006.11.032

[5] De Gennaro, L., Brunetti, N.D., Montrone, D., De Rosa, F., Cuculo, A. and Di Biase, M. (2012) Subacute Inflammatory Activation in Subjects with Acute Coronary Syndrome and Left Ventricular Dysfunction. Inflammation, 35, 363-370. http://dx.doi.org/10.1007/s10753-011-9326-4

[6] Lai, C.L., Ji, Y.R., Liu, X.H., Xing, J.P. and Zhao, J.Q. (2012) Relationship between Coronary Atherosclerosis Plaque Characteristics and High Sensitivity C-Reactive Proteins, Interleukin-6. Chinese Medical Journal (England), 124, 2452-2456.

[7] Scharnagl, H., Stojakovic, T., Weihrauch, G., Winkelmann, R.B., Boehm, B.O. and Maerz, W. (2010) Interleukin-6 Is Stronger Associated with All-Cause and Cardiovascularmortality than C-Reactive Protein, Serum Amyloid A and Fibrinogen (the Luric Study). Atherosclerosis Supplements, 11, 42. http://dx.doi.org/10.1016/S1567-5688(10)70191-4

[8] Fan, Z.X., Hua, Q., Li, Y.P., Liu, R.K. and Yang, Z. (2011) Interleukin-6, But Not Soluble Adhesion Molecules, Predicts a Subsequent Mortality from Cardiovascular Disease in Patients with Acute ST Segment Elevation Myocardial Infarction. Cell Biochemistry and Biophysics, 61, 443-448. http://dx.doi.org/10.1007/s12013-011-9209-1

[9] Armstrong, E.J., Morrow, D.A. and Sabatine, M.S. (2006) Inflammatory Biomarkers in Acute Coronary Syndromes Part I: Introduction and Cytokines. Circulation, 113, 72-75. http://dx.doi.org/10.1161/CIRCULATIONAHA.105.595520

[10] Luc, G. (2001) Inflammation Markers and Vascular Risk. La Revue de Médecine Interne, 25, S7-S9. http://dx.doi.org/10.1016/j.revmed.2004.04.005

[11] Wang, X.H., Liu, S.Q., Wang, Y.L. and Jin, Y. (2014) Correlation of Serum High-Sensitivity C-Reactive Protein and Interleukin-6 in Patients with Acute Coronary Syndrome. Genetics and Molecular Research, 13, 4260-4266. http://dx.doi.org/10.4238/2014.June.9.11

[12] Skoog, T., Dichtl, W., Boquist, S., Skoglund-Andersson, C., Karpe, F., Tang, R., et al. (2002) Plasma Tumour Necrosis Factor-Alpha and Early Carotid Atherosclerosis in Healthy Middle-Aged Men. European Heart Journal, 23, 376-383. http://dx.doi.org/10.1053/euhj.2001.2805

[13] Saraux, A., Gueguen, F., Jousse, S. and Bresollette, L. (2011) Anti-TNF Alpha et Risque Cardiovasculaire? Revue du Rhumatisme, 32, 41-44.

[14] Harris, T.B., Ferrucci, L., Tracy, R.P., Corti, M.C., Wacholder, S., Ettinger Jr., W.H., et al. (1999) Associations of Elevated Interleukin-6 and C-Reactive Protein Levels with Mortality in the Elderly. American Journal of Medicine, 106, 506-512. http://dx.doi.org/10.1016/S0002-9343(99)00066-2

[15] Ridker, P.M., Hennekens, C.H., Buring, J.E. and Rifai, N. (2000) C-Reactive Protein and Other Markers of Inflammation in the Prediction of Cardiovascular Disease in Women. The New England Journal of Medicine, 342, 836-843. http://dx.doi.org/10.1056/NEJM200003233421202

[16] Onat, A., Can, G. and Hergenc, G. (2008) Serum C-Reactive Protein Is an Independent Risk Factor Predicting Cardiometabolic Risk. Metabolism, 57, 207-214. http://dx.doi.org/10.1016/j.metabol.2007.09.002

[17] Li, J.J. and Fang, C.H. (2004) C-Reactive Protein Is Not Only an Inflammatory Marker but Also a Direct Cause of Cardiovascular Disease. Medical Hypotheses, 62, 499-506. http://dx.doi.org/10.1016/j.mehy.2003.12.014

[18] Vranken, G. (2004) CRP: Nouveau marqueur pour le pronostic des maladies cardiovasculaires [En ligne]. http://www.researchgate.net/publication/256387205_CRP_Nouveau_marqueur_pour_le_pronostic_des_maladies_car diovasculaires

[19] Chang, M.K., Binder, C.J., Torzewski, M. and Witztum, J.L. (2002) C-Reactive Protein Binds to Both Oxidized LDL and Apoptotic Cells through Recognition of a Common Ligand: Phosphorylcholine of Oxidized Phospholipids. Proceedings of the National Academy of Sciences of the United States of America, 99, 13043-13048. http://dx.doi.org/10.1073/pnas.192399699

[20] Zwaka, T.P., Hombach, V. and Torzewski, J. (2001) C-Reactive Protein-Mediated Low Density Lipoprotein Uptake by Macrophages: Implications for Atherosclerosis. Circulation, 103, 1194-1197. http://dx.doi.org/10.1161/01.CIR.103.9.1194

[21] Venugopal, S.K., Devaraj, S., Yuhanna, I., Shaul, P. and Jialal, I. (2002) Demonstration That C-Reactive Protein Decreases eNOS Expression and Bioactivity in Human Aortic Endothelial Cells. Circulation, 106, 1439-1441. http://dx.doi.org/10.1161/01.CIR.0000033116.22237.F9

[22] Devaraj, S., Xu, D.Y. and Jialal, I. (2003) C-Reactive Protein Increases Plasminogen Activator Inhibitor-1 Expression and Activity in Human Aortic Endothelial Cells: Implications for the Metabolic Syndrome and Atherothrombosis. Circulation, 107, 398-404. http://dx.doi.org/10.1161/01.CIR.0000052617.91920.FD 
[23] Tehrani, D.M., Gardin, J.M., Yanez, D., Hirsch, C.H., Lloyd-Jones, D.M., Stein, P.K., et al. (2013) Impact of Inflammatory Biomarkers on Relation of High Density Lipoprotein-Cholesterol with Incident Coronary Heart Disease: Cardiovascular Health Study. Atherosclerosis, 231, 246-251. http://dx.doi.org/10.1016/j.atherosclerosis.2013.08.036

[24] Calabresi, L., Gomaraschi, M., Villa, B., Omoboni, L., Dmitrieff, C. and Franceschini, G. (2002) Elevated Soluble Cellular Adhesion Molecules in Subjects with Low HDL-Cholesterol. Arteriosclerosis, Thrombosis, and Vascular Biology, 22, 656-661. http://dx.doi.org/10.1161/hq0402.105901

[25] Mascarenhas-Melo, F., Sereno, J., Teixeira-Lemos, E., Marado, D., Palavra, F., Pinto, R., et al. (2013) Implication of Low HDL-c Levels in Patients with Average LDL-c Levels: A Focus on Oxidized LDL, Large HDL Subpopulation, and Adiponectin. Mediators of Inflammation, 2013, Article ID: 612038. http://dx.doi.org/10.1155/2013/612038

[26] Wadham, C., Albanese, N., Roberts, J., Wang, L., Bagley, C.J., Gamble, J.R., et al. (2004) High-Density Lipoproteins Neutralize C-Reactive Protein Proinflammatory Activity. Circulation, 109, 2116-2122. http://dx.doi.org/10.1161/01.CIR.0000127419.45975.26

[27] Mineo, C., Deguchi, H., Griffin, J.H. and Shaul, P. (2006) Endothelial and Antithrombotic Actions of HDL. Circulation Research, 98, 1352-1364. http://dx.doi.org/10.1161/01.RES.0000225982.01988.93

[28] Wu, D.M., Chu, N.F., Shen, M.H. and Chang, J.B. (2003) Plasma C-Reactive Protein Levels and Their Relationship to Anthropometric and Lipid Characteristics among Children. Journal of Clinical Epidemiology, 56, 94-100. http://dx.doi.org/10.1016/S0895-4356(02)00519-X

[29] Demimbras, B., Guler, S., Cakir, B., Chulha, C. and Aral, Y. (2002) Plasma TNF- $\alpha$ Levels and Insulin Resistance in Non Diabetic Hypertensive Subjects. Hormone Research in Paediatrics, 58, 283-286. http://dx.doi.org/10.1159/000066447

[30] Jovinge, S., Hamsten, A., Torvall, P., Proudler, A., Bavenholm, P., Ericsson, C.G., et al. (1998) Evidence for a Role of Tumor Necrosis Factor Alpha in Disturbances of Triglyceride and Glucose Metabolism Predisposing to Coronary Heart Disease. Metabolism, 47, 113-118. http://dx.doi.org/10.1016/S0026-0495(98)90203-7

[31] Chen, X., Xun, K., Chen, L. and Wang, Y. (2009) TNF- $\alpha$, a Potent Lipid Metabolism Regulator. Cell Bioche- mistry and Function, 27, 407-416. http://dx.doi.org/10.1002/cbf.1596

[32] Popa, C., Netea, M.G., van Riel, P.L., Van Der Meer, J.W. and Stalenhoef, A.F. (2007) The Role of TNF- $\alpha$ in Chronic Inflammatory Conditions, Intermediary Metabolism, and Cardiovascular Risk. The Journal of Lipid Research, 48, 751762. http://dx.doi.org/10.1194/jlr.R600021-JLR200

[33] Vijaya, B.M., Prabhakara, R.P. and Balu, M.K. (2015) Correlative Association of Interleukin-6 with Malondialdehyde in Prehypertensive and Hypertensive Subjects. IOSR-JDMS, 14, 53-57.

[34] Zuliani, G., Volpato, S., Blè, A., Bandinelli, S., Corsi, A.M., Lauretani, F., et al. (2007) High Interleukin-6 Plasma Levels Are Associated with Low HDL-C Levels in Community-Dwelling Older Adults: The InChianti Study. Atherosclerosis, 192, 384-390. http://dx.doi.org/10.1016/j.atherosclerosis.2006.05.024

[35] Jin, W., Millar, J.S., Broedl, U., Glick, J.M. and Rader, D.J. (2003) Inhibition of Endothelial Lipase Causes Increased HDL Cholesterol Levels in Vivo. Journal of Clinical Investigation, 111, 357-362. http://dx.doi.org/10.1172/JCI16146

[36] Jin, W., Sun, G.S., Marchadier, D., Octtaviani, E., Glick, J.M. and Rader, D.J. (2003) Endothelial Cells Secrete Triglycerides Lipase and Phospolipase Activities in Response to Cytokines as a Result of Endothelial Lipase. Circulation Research, 92, 644-650. http://dx.doi.org/10.1161/01.RES.0000064502.47539.6D 